\title{
Allozyme Polymorphism and Genetic Differentiation Among Populations of Jaculus jaculus and J. orientalis (Rodentia: Dipodidae) in Tunisia
}

\author{
Abderraouf Ben Faleh ${ }^{1, *}$, Adel AB Shahin ${ }^{2}$, Khaled Said ${ }^{1}$ \\ (1. Unité de Recherche: Génétique, Biodiversité et Valorisation des Bio-ressources. Institut Supérieur de Biotechnologie de \\ Monastir 5000-Tunisie; 2. Department of Zoology, Faculty of Science, Minia University, 61519-El Minia, Egypt)
}

\begin{abstract}
Genetic variability and divergence among natural populations of Jaculus jaculus and J. orientalis in Tunisia were examined by electrophoretic analysis of 16 enzymatic proteins encoded by 23 genetic loci. Low levels of genetic variability were found among populations of both species in comparison to those of other rodent and mammal species of which data are available. In $J$. jaculus populations, the mean level of observed heterozygosity $\left(H_{\mathrm{obs}}\right)$ ranged from 0.08 to 0.19 , while the mean percentage of polymorphic loci $(P)$ ranged from $26.2 \%$ to $45.2 \%$ and the mean number of alleles per locus (A) ranged from 1.1 to 1.4 . Nevertheless, the mean values were 0.10 to $0.15,29.3 \%$ to $44.1 \%$ and 1.1 to 1.7 , respectively, for $J$. orientalis. In addition, populations of the two species have revealed a lower degree of genetic differentiation $\left(F_{\mathrm{st}}=0.0017\right.$ for $J$. jaculus and 0.0019 for $J$. orientalis). Moreover, $F_{\text {st }}$ was $0.607, P<0.05$ between populations of the two species, indicating that they were highly genetically diverged from each other. The present data assures the previous results on the validity of the present taxonomic situation of the two species and emphasis on the effect of geographic factors (environments type and bioclimatic stages) on the genetic structure of both species.
\end{abstract}

Key words: Dipodidae; Jerboas; Allozyme; Electrophoresis; Tunisia

\section{突尼斯非洲跳鼠(Jaculus jaculus)和埃及跳鼠(J. orientalis) 群体的等位酶多态及遗传分化}

\author{
Abderraouf Ben Faleh ${ }^{1, *}$, Adel AB Shahin ${ }^{2}$, Khaled Said ${ }^{1}$ \\ (1. Unité de Recherche: Génétique, Biodiversité et Valorisation des Bio-ressources. Institut Supérieur de Biotechnologie de \\ Monastir 5000-Tunisie; 2. Department of Zoology, Faculty of Science, Minia University, 61519-El Minia, Egypt)
}

摘要: 运用 16 种酶蛋白编码的 23 个遗传座位对突尼斯非洲跳鼠(Jaculus jaculus)和埃及跳鼠(J. orientalis)自然 群体的遗传变异和分化进行了电泳分析。结果表明, 与其他啮齿动物等哺乳动物的相关数据比较, 发现这两个种群 体的遗传变异水平较低。非洲跳鼠群体的观测杂合度 $\left(H_{\mathrm{obs}}\right)$ 为 $0.08-0.19$, 多态座位百分比 $(\mathrm{P})$ 为 $26.2 \%-45.2 \%$, 每个座位的平均等位基因数 $(\mathrm{A})$ 为 $1.1-1.4$; 埃及跳鼠的 $H_{\mathrm{obs}}$ 为 $0.10-0.15, P$ 为 $29.3 \%-44.1 \%, \mathrm{~A}$ 为 $1.1-1.7$ 。两 个种群体各自的遗传分化程度较低(非洲跳鼠和埃及跳鼠的 $F_{\mathrm{st}}$ 分别为 0.0017 和 0.0019 )。而两个种群体间的 $F_{\mathrm{st}}$ 为 $0.607(P<0.05)$, 表明两个种之间高度的遗传分化。本研究支持这两个种分类地位的合法性, 并强调了地理因素 （环境类型和生物气候阶段）对两个种遗传结构的影响。

关键词: 跳鼠科; 跳鼠; 等位酶; 电泳; 突尼斯

中图分类号: Q959.837; Q347; Q958.2 文献标识码：A＼cjkstart文章编号：0254-5853-(2009)03-0247-08

The genus Jaculus (Erxleben, 1777) basically contains two morphologically distinct species, lesser jerboa J. jaculus (Linnaeus, 1758) and greater jerboa $J$. orientalis (Erxleben, 1777), that occur in very diverse habitats throughout the sub-Saharan and deserts of North Africa, Asia, and Arabian countries such as Egypt, Sudan,
Israel and Morocco (Osborn \& Helmy, 1980; Aulagnier \& Thévenot, 1986; Brown, 1994; Kingdon, 1997). The taxonomy of these species has received a considerable attention and has been the subject to controversial discussion. Pocock (1922) placed J. jaculus into the genus Jaculus and J. orientalis into the genus Scirtopoda

Received date: 2009-01-04; Accepted date: 2009-05-18

*Corresponding author（通讯作者）,E-mail: benfalahabdelraouf@yahoo.fr

收稿日期：2009-01-04; 接受日期：2009-05-18 
(Fischer, 1817) due to differences in the external genitalia. However, on the basis of cranial and dental characters, Vinogradov (1930) reclassified J. orientalis to the genus Jaculus. This taxonomic controversy has evoked several additional studies on the Egyptian dipodids to clarify their taxonomic relationship. For example, osteology studies revealed that both J. jaculus and $J$. orientalis are more closely related to each other (Wassif, 1960). Chromosomal studies supported this hypothesis and interpreted the dissimilarity in the G-bands of the morphologically different chromosome pairs between the two species as pericentric inversions (Ata \& Shahin, 1999; Ata et al, 2001; Shahin \& Ata, 2001). Moreover, estimates of genetic divergence deduced from allozymic survey (Shahin, 2003) have shown that $J$. orientalis appears to have shared a more recent common ancestor with $J$. jaculus than Allactaga tetradactyla. Divergence of these species would have occurred by Miocene (ca 9.6 to 18.7 million years ago).

In Tunisia, the lesser jerboa $J$. jaculus is almost common in desert areas, while the greater jerboa $J$. orientalis occurs almost in the semiarid regions in the North. Due to the differences in the morphological features and ecological habitats of the two species as well as the lack of genetic investigations on both of them in Tunisia, the present study was undertaken to examine the allozymic variability and genetic divergence among populations of J. jaculus and J. orientalis.

\section{Materials and Methods}

\subsection{Samples}

Adult individuals of both the lesser jerboa Jaculus jaculus and greater jerboa $J$. orientalis were collected in Tunisia between 2005 and 2007 from all currently known localities of their distribution as described by Burhan (1997). A total of 300 specimens collected from 12 localities (six populations for each species) were live trapped and examined. Samples of J. jaculus were collected from Matmata, Nefta, Tataouine, Hamma, Gabes and Mednine, while those of J. orientalis were trapped from Mateur, El Khouat, Amra, Boumerdes, Oueslatia and Lessouda (Fig. 1).

\subsection{Methods}

Tissues from each specimen were preserved at $-80^{\circ} \mathrm{C}$ until processed. Homogenates for electrophoresis were obtained from fractions of liver, muscle or kidney tissue crushed in distilled water. Horizontal starch gel (12\%) electrophoresis of allozymes was carried out according to the protocols described in Harris \& Hopkinson (1976) and Pasteur et al (1986). Twenty-three putative loci encoding 16 enzymatic proteins were analyzed using four different buffers (Tab. 1).

Tab. 1 Enzymatic and non-enzymatic proteins surveyed among the populations of Jaculus jaculus and $J$. orientalis examined

\begin{tabular}{|c|c|c|c|c|c|}
\hline Enzyme & Locus & E.C & Polymorphism & Tissue & Buffer, $\mathrm{pH}$ \\
\hline Isocitrate deshydrogenase & $\begin{array}{l}\text { Idh-1 } \\
\text { Idh-2 }\end{array}$ & 1.1.1.42 & $\begin{array}{l}\mathrm{P} \\
\mathrm{P}\end{array}$ & Kidney & $\mathrm{TC}, 6.7$ \\
\hline Malic enzyme & Mod-1 & 1.1 .1 .40 & $\mathrm{P}$ & Kidney & $\mathrm{TC}, 8.0$ \\
\hline Superoxide dismutase & Sod-1 & 1.15 .1 .1 & $\mathrm{P}$ & Kidney & $\mathrm{TC}, 6.7$ \\
\hline Glucose phosphate isomerase & Gpi-1 & 5.3.1.9 & $\mathrm{P}$ & Kidney & $\mathrm{TC}, 6 . .7$ \\
\hline Phosphogluconate dehydrogenase & Pgd-1 & 1.1.1.44 & $\mathrm{P}$ & Liver & $\mathrm{TC}, 8.0$ \\
\hline Aspartate aminotransferase & $\begin{array}{l}\text { Aat-1 } \\
\text { Aat-2 }\end{array}$ & 2.6.1.1 & $\begin{array}{l}\mathrm{P} \\
\mathrm{P}\end{array}$ & Liver & TME, 6.9 \\
\hline Glucose-6-phosphate dehydrogenase & G6pd-1 & 1.1.1.49 & $\mathrm{P}$ & Liver & TME, 6.9 \\
\hline Sorbitol dehydrogenase & $S d h-1$ & 1.1 .1 .14 & $\mathrm{P}$ & Kidney & $\mathrm{TC}, 8.0$ \\
\hline Alcohol dehydrogenase & Adh-1 & 1.1.1.1 & $\mathrm{P}$ & Liver & TME, 6.9 \\
\hline Mannose phosphate isomerase & $M p i-1$ & 5.3.1.8 & $\mathrm{P}$ & Kidney & $\mathrm{TC}, 6.7$ \\
\hline Esterase & Es-2 & 3.1 .1 .1 & $\mathrm{P}$ & Kidney & LI OH, 8.3 \\
\hline Phosphoglucomutase & Pgm-1 & 2.5 .7 .1 & $\mathrm{P}$ & Liver & TME, 6.9 \\
\hline Lactate dehydrogenase & $\begin{array}{l}L d h-1 \\
L d h-2 \\
L d h-3\end{array}$ & 1.1 .1 .27 & $\begin{array}{l}\mathrm{M} \\
\mathrm{M} \\
\mathrm{M}\end{array}$ & Kidney & $\mathrm{TC}, 6.7$ \\
\hline Malate dehydrogenase & $\begin{array}{l}M d h-1 \\
M d h-2\end{array}$ & 1.1.1.37 & $\begin{array}{l}\mathrm{M} \\
\mathrm{M}\end{array}$ & Kidney & $\mathrm{TC}, 6.7$ \\
\hline Adenylate kinase & $\begin{array}{l}A k-1 \\
A k-2\end{array}$ & 2.7 .4 .3 & $\begin{array}{l}\mathrm{M} \\
\mathrm{M}\end{array}$ & Kidney & $\mathrm{TC}, 6.7$ \\
\hline Creatine kinase & $\begin{array}{l}C k-1 \\
C k-2\end{array}$ & 2.7 .3 .2 & $\begin{array}{l}\mathrm{M} \\
\mathrm{M}\end{array}$ & Kidney & $\mathrm{TC}, 6.7$ \\
\hline
\end{tabular}


Tab. 2 Allele frequencies at the 14 polymorphic loci surveyed among populations of Jaculus jaculus and

J. orientalis examined

\begin{tabular}{|c|c|c|c|c|c|c|c|c|c|c|c|c|}
\hline \multirow[b]{3}{*}{ Locus } & \multicolumn{12}{|c|}{ Locality and sample size $(\mathrm{N})$} \\
\hline & \multicolumn{6}{|c|}{ J. orientalis } & \multicolumn{6}{|c|}{ J. jaculus } \\
\hline & $\begin{array}{l}\text { Mateur } \\
N=25\end{array}$ & $\begin{array}{c}\text { El } \\
\text { Khou- } \\
\text { at } \\
N=25 \\
\end{array}$ & $\begin{array}{c}\text { Bou- } \\
\text { merd- } \\
\text { es } \\
N=25\end{array}$ & $\begin{array}{l}\text { Ouesl- } \\
\text { atia } \\
N=25\end{array}$ & $\begin{array}{l}\text { Amra } \\
N=25\end{array}$ & $\begin{array}{c}\text { Lesso- } \\
\text { uda } \\
N=25\end{array}$ & $\begin{array}{c}\text { Matm- } \\
\text { ata } \\
N=25\end{array}$ & $\begin{array}{l}\text { Nefta } \\
N=25\end{array}$ & $\begin{array}{l}\text { Tatao- } \\
\text { uine } \\
N=25\end{array}$ & $\begin{array}{l}\text { Medn- } \\
\text { ine } \\
N=25\end{array}$ & $\begin{array}{c}\text { Ham- } \\
\text { ma } \\
N=25\end{array}$ & $\begin{array}{l}\text { Gabes } \\
N=25\end{array}$ \\
\hline \multicolumn{13}{|l|}{ Est-2 } \\
\hline 100 & 0.9750 & 0.7500 & 0.8000 & 0.7750 & 0.5750 & 0.5500 & 0.4000 & 0.4000 & 0.3750 & 0.3500 & 0.1750 & 0.3000 \\
\hline 110 & 0.0250 & 0.2500 & 0.2000 & 0.1750 & 0.4250 & 0.4000 & 0.1250 & 0.0250 & 0.0500 & 0.0250 & 0.0750 & 0.0000 \\
\hline 120 & 0.0000 & 0.0000 & 0.0000 & 0.0500 & 0.0000 & 0.0500 & 0.4750 & 0.5750 & 0.5750 & 0.6250 & 0.7500 & 0.7000 \\
\hline \multicolumn{13}{|l|}{ Mod-1 } \\
\hline 070 & 0.8250 & 0.8000 & 0.7000 & 0.7500 & 0.8250 & 0.5500 & 0.3250 & 0.3500 & 0.3250 & 0.3500 & 0.3000 & 0.1750 \\
\hline 080 & 0.1750 & 0.2000 & 0.2750 & 0.2500 & 0.1750 & 0.4500 & 0.0250 & 0.0000 & 0.1500 & 0.0250 & 0.0000 & 0.0750 \\
\hline 090 & 0.0000 & 0.0000 & 0.0250 & 0.0000 & 0.0000 & 0.0000 & 0.6500 & 0.6500 & 0.5250 & 0.6250 & 0.7000 & 0.7500 \\
\hline \multicolumn{13}{|l|}{ Sod-1 } \\
\hline 100 & 0.9250 & 0.7250 & 0.7500 & 0.8000 & 0.8500 & 0.9250 & 0.3500 & 0.3500 & 0.2500 & 0.2250 & 0.2000 & 0.0250 \\
\hline 110 & 0.0750 & 0.2750 & 0.2500 & 0.2000 & 0.1500 & 0.0750 & 0.6500 & 0.6500 & 0.7500 & 0.7750 & 0.8000 & 0.9750 \\
\hline \multicolumn{13}{|l|}{$I d h-1$} \\
\hline 100 & 0.9250 & 0.9750 & 0.8750 & 0.9500 & 0.8750 & 0.8500 & 0.2250 & 0.1500 & 0.2000 & 0.4250 & 0.1500 & 0.2250 \\
\hline 110 & 0.0750 & 0.0250 & 0.1250 & 0.0500 & 0.1250 & 0.1500 & 0.7750 & 0.8500 & 0.8000 & 0.5750 & 0.8500 & 0.7750 \\
\hline \multicolumn{13}{|l|}{$I d h-2$} \\
\hline 080 & 0.8250 & 0.9000 & 0.9250 & 0.8250 & 0.8750 & 0.9250 & 0.1750 & 0.1500 & 0.1250 & 0.1750 & 0.3000 & 0.2250 \\
\hline 090 & 0.1750 & 0.1000 & 0.0750 & 0.1750 & 0.1250 & 0.0750 & 0.8250 & 0.8500 & 0.8750 & 0.8250 & 0.7000 & 0.7750 \\
\hline \multicolumn{13}{|l|}{ Pgd-1 } \\
\hline 080 & 0.8250 & 0.5500 & 0.7250 & 0.7250 & 0.8000 & 0.7500 & 0.2750 & 0.1250 & 0.3000 & 0.1750 & 0.3500 & 0.3750 \\
\hline 090 & 0.1750 & 0.4500 & 0.2750 & 0.2750 & 0.2000 & 0.2500 & 0.0250 & 0.1000 & 0.0000 & 0.0750 & 0.0250 & 0.0500 \\
\hline 100 & 0.0000 & 0.0000 & 0.0000 & 0.0000 & 0.0000 & 0.0000 & 0.7000 & 0.7750 & 0.7000 & 0.7500 & 0.6250 & 0.5750 \\
\hline \multicolumn{13}{|l|}{ Aat-1 } \\
\hline 080 & 0.9000 & 0.8250 & 0.8250 & 0.8500 & 0.7750 & 0.8750 & 0.1750 & 0.1500 & 0.2250 & 0.1500 & 0.0500 & 0.8500 \\
\hline 090 & 0.1000 & 0.1750 & 0.1750 & 0.1500 & 0.2250 & 0.1250 & 0.8250 & 0.8500 & 0.7750 & 0.8500 & 0.9500 & 0.1500 \\
\hline \multicolumn{13}{|l|}{ Aat-2 } \\
\hline 100 & 0.8750 & 0.8500 & 0.8500 & 0.9250 & 0.8750 & 0.1250 & 0.2000 & 0.3000 & 0.0250 & 0.0500 & 0.0250 & 0.2250 \\
\hline 110 & 0.1250 & 0.1500 & 0.1500 & 0.0750 & 0.1250 & 0.8750 & 0.8000 & 0.7000 & 0.9750 & 0.9500 & 0.9750 & 0.7750 \\
\hline \multicolumn{13}{|l|}{ G6pd1 } \\
\hline 100 & 1.0000 & 1.0000 & 1.0000 & 1.0000 & 1.0000 & 1.0000 & 0.0000 & 0.0000 & 0.0000 & 0.0000 & 0.0000 & 0.0000 \\
\hline 110 & 0.0000 & 0.0000 & 0.0000 & 0.0000 & 0.0000 & 0.0000 & 1.0000 & 1.0000 & 1.0000 & 1.0000 & 1.0000 & 1.0000 \\
\hline \multicolumn{13}{|l|}{ Sdh-1 } \\
\hline 090 & 0.4250 & 0.5750 & 0.5500 & 0.4750 & 0.8000 & 0.7750 & 0.1000 & 0.3000 & 0.0750 & 0.1750 & 0.1250 & 0.3500 \\
\hline 100 & 0.5750 & 0.3250 & 0.4500 & 0.4250 & 0.2000 & 0.1750 & 0.1000 & 0.0500 & 0.1250 & 0.1750 & 0.1000 & 0.0250 \\
\hline 110 & 0.0000 & 0.1000 & 0.0000 & 0.1000 & 0.0000 & 0.0500 & 0.4750 & 0.3250 & 0.5500 & 0.3250 & 0.7750 & 0.6250 \\
\hline 120 & 0.0000 & 0.0000 & 0.0000 & 0.0000 & 0.0000 & 0.0000 & 0.3250 & 0.3250 & 0.2500 & 0.3250 & 0.0000 & 0.0000 \\
\hline \multicolumn{13}{|l|}{ Adh-1 } \\
\hline 090 & 0.5750 & 0.5500 & 0.6500 & 0.5250 & 0.5500 & 0.4250 & 0.0500 & 0.1500 & 0.1250 & 0.0750 & 0.0750 & 0.1750 \\
\hline 100 & 0.4250 & 0.4000 & 0.2500 & 0.4000 & 0.4500 & 0.5750 & 0.0000 & 0.1000 & 0.0000 & 0.0500 & 0.1250 & 0.1750 \\
\hline 110 & 0.0000 & 0.0500 & 0.1000 & 0.0750 & 0.0000 & 0.0000 & 0.8000 & 0.5000 & 0.5000 & 0.5500 & 0.5500 & 0.3250 \\
\hline 120 & 0.0000 & 0.0000 & 0.0000 & 0.0000 & 0.0000 & 0.0000 & 0.1500 & 0.2500 & 0.3750 & 0.3250 & 0.2500 & 0.3250 \\
\hline \multicolumn{13}{|l|}{ Mpi-1 } \\
\hline 100 & 0.9250 & 0.8750 & 0.9000 & 0.7750 & 0.8250 & 0.7250 & 0.1250 & 0.0250 & 0.1500 & 0.1750 & 0.2250 & 0.0500 \\
\hline 110 & 0.0750 & 0.1250 & 0.1000 & 0.2250 & 0.1750 & 0.2750 & 0.8750 & 0.9750 & 0.8500 & 0.8250 & 0.7750 & 0.9500 \\
\hline \multicolumn{13}{|l|}{ Pgm-1 } \\
\hline 100 & 0.8750 & 0.8500 & 0.8500 & 0.9250 & 0.8750 & 0.2250 & 0.2000 & 0.3000 & 0.0250 & 0.1250 & 0.0250 & 0.0500 \\
\hline 110 & 0.1250 & 0.1500 & 0.1500 & 0.0750 & 0.1250 & 0.7750 & 0.8000 & 0.7000 & 0.9750 & 0.8750 & 0.9750 & 0.9500 \\
\hline Gpi-1 & & & & & & & & & & & & \\
\hline 110 & 0.9250 & 0.9000 & 0.1250 & 0.9250 & 0.8750 & 0.8500 & 0.8500 & 0.2250 & 0.8000 & 0.6500 & 0.2250 & 0.8500 \\
\hline 120 & 0.0750 & 0.1000 & 0.8750 & 0.0750 & 0.1250 & 0.1500 & 0.1500 & 0.7750 & 0.2000 & 0.3500 & 0.7750 & 0.1500 \\
\hline
\end{tabular}

\subsection{Data analysis}

Observed electromorphs or alleles were identified herein according to their electrophoretic mobility relative to that of the most common electromorph (assigned 
mobility=100). Gene frequencies and genetic variability parameters were calculated using the GENETIX 4.03 software (Belkhir et al, 2001). The standardized genetic variance $\left(F_{\mathrm{st}}\right)$ among all populations was estimated for the polymorphic loci and the significance of the $F_{\text {st }}$ values was tested using Monte Carlo simulations in ARLEQUIN 3.0 (Excoffier et al, 2005). Nei's (1972) genetic distance $(D)$ matrices between populations were calculated using the program GENDIST from the PHYLIP 3.5 package (Felsenstein, 1993), which was then used for the construction of the phenogram by the UPGMA (Sneath \& Sokal, 1973). Bootstrap values were obtained from 1000 pseudo replicates of allele frequencies using the SEQBOOT routine in PHYLIP. The sequential Bonferroni's test (Rice, 1989) was used to correct for multiple tests.

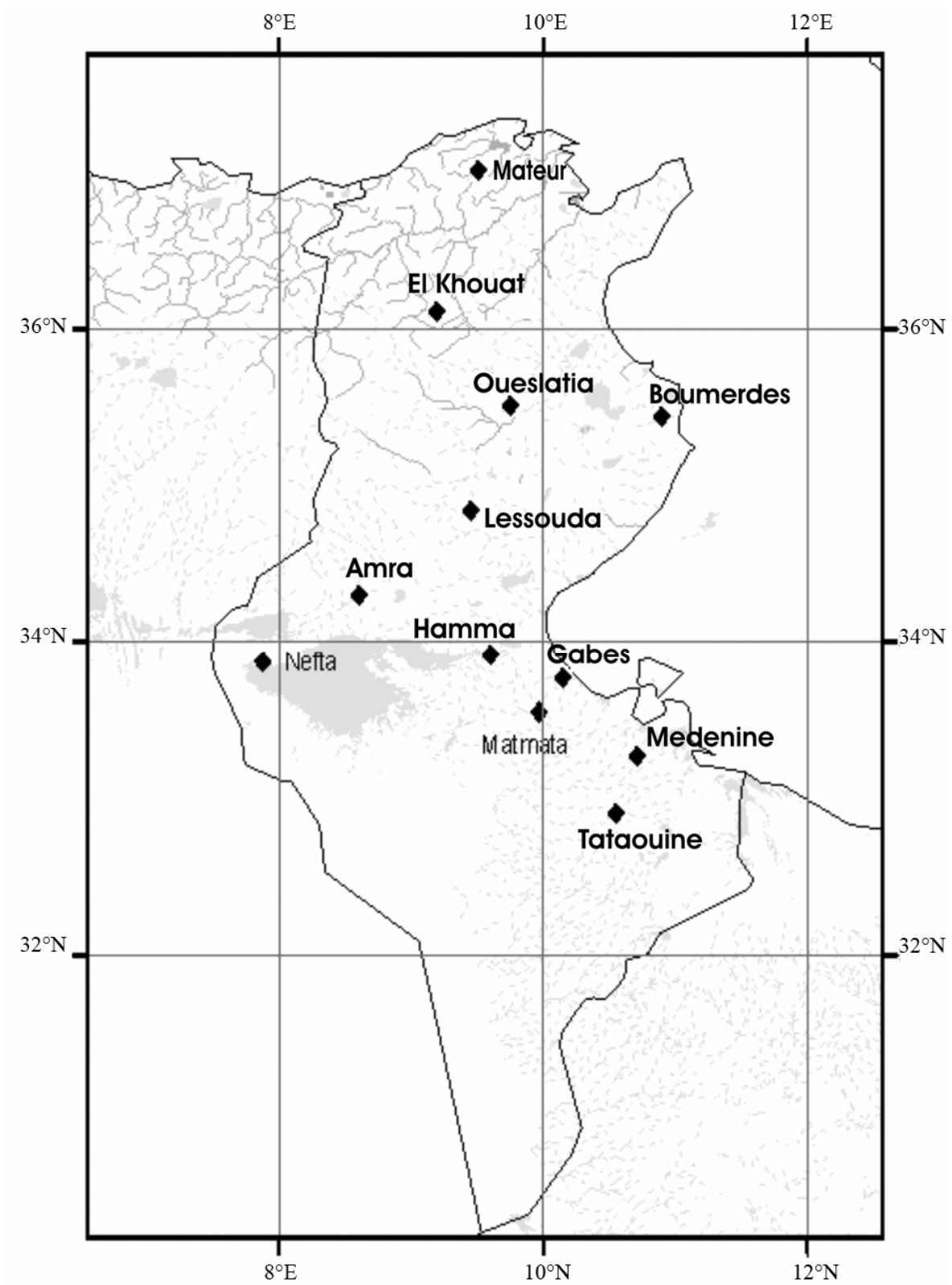

Fig. 1 A map showing the geographical localities from which the populations of both Jaculus jaculus and J. orientalis were collected in Tunisia

\section{Results}

Twenty-three loci encoding 16 enzymatic systems were compared among populations of the two studied jerboa species. Of these 23 loci, only nine (39\%) loci (Ldh-1, Ldh-2, Ldh-3, Mdh-1, Mdh-2, Ak-1, Ak-2, Ck-1 and $C k-2)$ were monomorphic with the same allele fixed in all populations, while the remaining $14(61 \%)$ loci 
were polymorphic with different alleles (Tab. 2).

\subsection{Intraspecific genetic structure}

A summary of genetic data on the 12 populations of the two dipodid species is given in Tab. 3. The observed heterozygosity $\left(H_{\mathrm{obs}}\right)$ ranged from 0.10 to 0.15 in $J$. jaculus, while it varied between 0.08 and 0.19 in $J$. orientalis. However, larger values of the percentage of polymorphic loci $(P)$ were noted in both species; it ranged from $27.28 \%$ to $44.11 \%$ in $J$. orientalis and $22.12 \%$ to $45.19 \%$ in J. jaculus. Similarly, allelic richness (number of alleles per locus (A) exhibited higher levels in both J. jaculus (range from 1.09 to 1.65) and J. orientalis (range from 1.11 to 1.42 ).

It is worthy to mention that an absence of the genetic differentiation was noted in the populations of the two species. This was clearly demonstrated by the relatively lower levels of $F_{\text {st }}$ and Nei's distance. In the lesser Jerboa J. jaculus, $F_{\text {st }}$ value was 0.0017 and Nei's distance $(0.0016)$, while in the greater jerboa J. orientalis, they were 0.0019 and 0.0018 , respectively. These lower values of both $F_{\text {st }}$ and Nei's distance in both species reflect a high genetic homogeneity and a clear high gene flow among their populations (Tab. 4).

\subsection{Interspecific genetic relationship}

A clear difference in allelic frequencies and distribution was noted between the two species. In addition, the two species were genetically highly differentiated and the $F_{\text {st }}$ and Nei's (1972) distance between the two species were 0.61 and 0.56 , respectively. A diagnostic locus (G6pd-1) as well as remarkable differences in allelic frequencies and distribution were noted between the two species and yielded two separate clades by means of UPGMA analysis corresponding to the lesser jerboa and greater jerboa, respectively (Fig. 2).

\section{Discussion}

Allozyme analysis of the 23 genetic loci showed that the values of genetic variation $\left(H_{\mathrm{obs}}, P\right.$ and $\left.\mathrm{A}\right)$ observed in Jaculus jaculus and $J$. orientalis are generally within the range reported for other rodent species of which data are available (Nevo et al, 1990) and slightly higher than those reported for the same species in Egypt (Shahin, 2003).

Analysis of our data suggests that only low differentiation were found between local populations of the two species, as exemplified by the low values of genetic distances and $F_{\text {st }}$. This result of close similarity in genetic content between local populations of the same taxon seemingly characterizes all types of organisms for which further data are available (Selander \& Johnson, 1973; Avise, 1974; Ayala, 1975). Estimates of levels of genetic similarity suggest that the dipodids examined here were comparatively either within the range or quite different from other taxa (Nevo et al, 1974; Avise \& Smith, 1977; Gardenal et al, 1990; De Sousa et al, 1996). Significant correlation between levels of genetic diversity and ecological parameters (life zone, geographical range, habitat type and range, and climate region), demographic parameters (species size and population structure, gene flow and sociability), and a series of life history characteristics (longevity, generation length, fecundity, origin and parameters related to the mating system mode of reproduction) has previously been reported (Nevo et al, 1984).

Tab. 3 A summary of genetic variability in the populations of Jaculus jaculus and J. orientalis examined based on electrophoretic analysis of 23 loci

\begin{tabular}{clcccc}
\hline \multirow{2}{*}{ Species } & Populations & $\begin{array}{c}\text { Mean no. of } \\
\text { alleles per } \\
\text { locus }(A)\end{array}$ & $\begin{array}{c}\text { Percentage of } \\
\text { polymorphic loci }\end{array}$ & $(P)$ & \multicolumn{2}{c}{ Mean heterozygosity } \\
\cline { 4 - 6 } & Mateur & 1.23 & 44.11 & $H_{\text {obs }}$ & $H_{\text {exp }}$ \\
& El Khouat & 1.17 & 34.15 & $0.1114 \pm 0.0378$ & $0.1371 \pm 0.0280$ \\
& Boumerdes & 1.43 & 29.27 & $0.1171 \pm 0.0646$ & $0.1140 \pm 0.0266$ \\
J. orientalis & Oueslatia & 1.24 & 41.18 & $0.0964 \pm 0.0646$ & $0.1173 \pm 0.0426$ \\
& Amra & 1.65 & 35.98 & $0.1536 \pm 0.0308$ & $0.1884 \pm 0.0237$ \\
& Lessouda & 1.09 & 27.28 & $0.1314 \pm 0.0469$ & $0.1707 \pm 0.0695$ \\
& Mean & 1.31 & 35.33 & $0.1175 \pm 0.0427$ & $0.1420 \pm 0.0405$ \\
\hline \multirow{5}{*}{ J. Jaculus } & Matmata & 1.42 & 31.18 & $0.1629 \pm 0.0132$ & $0.1996 \pm 0.0730$ \\
& Nefta & 1.11 & 45.19 & $0.1886 \pm 0.0145$ & $0.1927 \pm 0.0550$ \\
& Tataouine & 1.23 & 22.12 & $0.0814 \pm 0.0469$ & $0.1084 \pm 0.0237$ \\
& Mednine & 1.39 & 28.15 & $0.1929 \pm 0.0132$ & $0.2007 \pm 0.0695$ \\
& Hamma & 1.16 & 26.18 & $0.1386 \pm 0.0145$ & $0.1896 \pm 0.0730$ \\
& Gabes & 1.29 & 44.01 & $0.1186 \pm 0.0145$ & $0.1727 \pm 0.0550$ \\
& Mean & 1.27 & 32.81 & $0.1472 \pm 0.0195$ & $0.1773 \pm 0.0582$ \\
\hline
\end{tabular}


Tab. 4 Pairwise estimates of $F_{\text {st }}$ values between the populations of Jaculus jaculus and $J$. orientalis based on the 14 polymorphic loci are given above (diagonal) and the genetic distances (Nei, 1972) are below (diagonal). The correct values of sequential Bonferroni's test between the two species are added

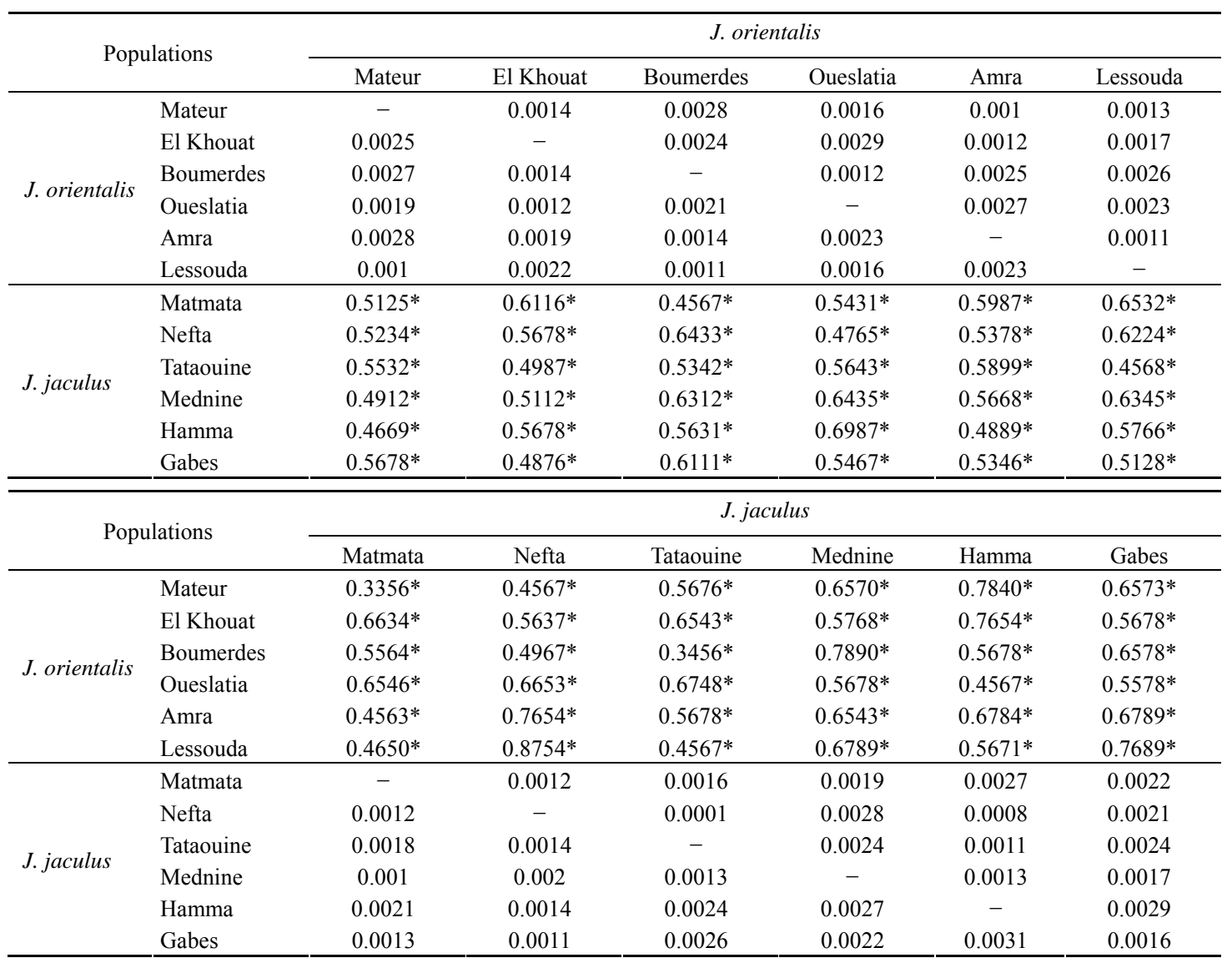

* Significant after correction Bonferronni's.

In the present investigation, similar explanation linked to genetic variability and genetic differentiation in $J$ jaculus and $J$. orientalis, could be assumed when comparing the present data with that of the Egyptian species (Shahin, 2003).

The main causes of genetic variability and relatively low heterozygosity exhibited by the studied populations have been discussed by several authors. For example, it has been reported that both random and deterministic factors, including genetic drift, selection, migration, mutation and historic events, may affect the population size and breeding and thereby causing homozygosity and reducing heterozygosity (Nevo et al, 1974). In addition, an increase in genetic variability could be adaptative strategy in an unexpected environment (Nevo, 1978), and variability could also remain weak in an ecologically diversified environment (Pasteur et al, 1978). Moreover, under stable conditions in a uniform trophic environment, genetic variability could accumulate (Ayala \& Valentine, 1974). Furthermore, it has been pointed out that the genetic variation observed among populations living in nearly stable environmental conditions could be suggestive of differences in vagility and breeding (Gorman et al, 1977). Normally, high vagility and consequent low inbreeding results in relatively high levels of genetic variation. Thus, like in many other rodent species, the considerable levels of genetic variability observed in these dipodid species could be explained as an adaptative strategy for homozygosity in the relatively uniform environment (Shahin, 2003). On the other hand, the significant increase of heterozygotes more than expected among the dipodid species examined in this study may be due to: selection, either for the heterozygotes or against the homozygotes, negative assortative mating, or any other special explanation, that the heterozygotes are more active than homozygotes and that they are frequently more trapped (Shahin, 2003). Nevertheless, the low intraspecific $F_{\text {st }}$ and Nei's distance, observed in this study, may be explained by high gene flow among populations linked probably to high vagility of both species (Anderson, 1970; Wolff, 2008). These findings are in accordance with those found in Egyptian 


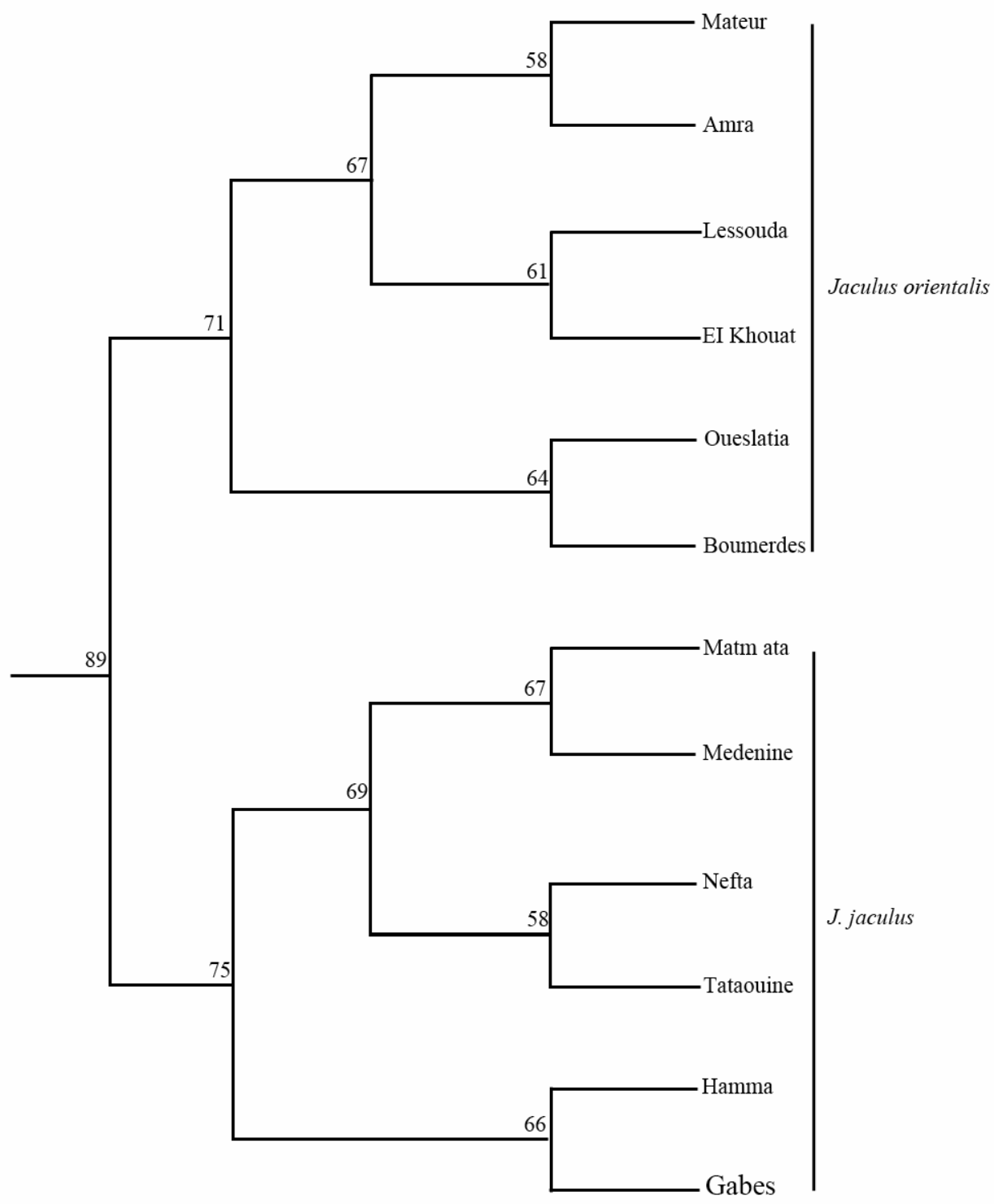

Fig. 2 A phenogram constructed based on Nei's (1972) genetic distance (D) matrices between the populations of Jaculus jaculus and J. orientalis examined

counterparts (Shahin, 2003). When interspecific distances are compared between species, higher values were noted indicating probably the effect of the bioclimatic factors on the genetic differentiation between species. Indeed, $J$. jaculus occupies the southern parts of Tunisia, mainly desert areas, while $J$. orientalis is common in the north of Tunisia occupying mountains and dense vegetations.

In conclusion, the genetic relationship between the two species examined, as demonstrated by the phylogenetic tree, is generally similar to that reported for the same species in Egypt (Shahin, 2003) and indicates that the divergence of the two species from their common ancestor has occurred since 3 millions years ago. In addition, the present data assures the validity of the present taxonomic situation of the two species and emphasis on the effect of geographic factors (environments type and bioclimatic stages) on the genetic structure of both species.

Acknowledgements: The authors are grateful to $\mathrm{Mr}$. Amor BEN AMOR for collecting the samples. 


\section{References:}

Anderson PK. 1970. Ecological structure and gene flow in small mammals[J]. Symp Zool Soc London, 26: 299-325.

Ata AM, Shahin AAB, Allam HZ. 2001. A Comparative analysis of the rate of meiosis, chiasma frequency and terminalization in the jerboas Allactaga and Jaculus (Rodentia: Dipodidae) in Egypt[J]. Folia Biol (Krakow), 49: 129-135.

Ata AM, Shahin AAB. 1999. Variation of G-bands in the chromosomes of Allactaga tetradactyla, Jaculus jaculus and Jaculus orientalis (Rodentia: Dipodidae) common in Egypt[J]. J Union of Arab Biologists, 11: 295-309.

Aulagnier S, Th"| venot M. 1986. Catalogue des mammifères sauvages du Maroc. Travaux de l'Institut Scientifique[J]. Sèrie Zool, 41: $1-164$.

Avise JC. 1974. Systematic value of electrophoretic data[J]. Syst Zool, 23: 465-481.

Avise JC, Smith MH. 1977. Gene frequency comparaisons between sunfish (Centrarchidae) populations at various stages of evolutionnary divergence[J]. Syst Zool, 26: 319-335.

Ayala FJ. 1975. Genetic differentiation during the speciation process[A]. In: Dobzansky T, Hecht MK, Stree WC. Evolutionary Biology[M]. Appeleton-Century-Crofts (New York), 8: 1-78.

Ayala FJ, Valentine JW. 1974. Genetic variability in the cosmopolitan deep-water Ophiuran, Opkiomusium lymani[J]. Marine Biol, 27: 51-57.

Belkhir K, Borsa P, Chikhi L, Raufaste N, Bonhomme F. 2001. GENETIX, Logiciel sous Windows TM pour la Gènètique des Populations. Laboratoire Gènome et Populations, Interactions, Adaptations, CNRS UMR 5000, Universitè de Montpellier II, Montpellier, France.

Brown JS. 1994. Coexistence of Negev Desert Rodents[J]. Ecology, 75: 2290-2297.

Burhan MG. 1997. Systematics, distribution, and zoogeography of mammals of Tunisia. Thesis[D]. Texas Tech University, 354.

De Sousa GB, De Rosa N, Gardenal CN. 1996. Protein polymorphism in Eligmodontia typus. Genetic divergence with order phyllotine cricetids[J]. Genetica, 97: 47-53.

Excoffier L, Laval G, Schneider S. 2005. Arlequin ver.3.0: an integrated software package for population genetics data analysis[J]. Evol Bioinformat Online, 1: 47-50.

Felsenstein J. 1993. PHYLIP (Phylogeny Inference Package), Version 3.5C. University of Washington, Seattle, WA, USA.

Gardenal CN, Garcia BA, Sabattini MS, Blanco A. 1990. Protein polymorphism and genetic distance in South American cricetid rodent of the genus Calomys[J]. Genetica, 80: 175-180.

Gorman GC, Kim YJ, Taylor CHE. 1977. Genetic variation in irradiated and control populations in Cnemidophorus tigris (Ssauria, Teiidae) from Mercury, Nevada with a discussion of genetic variability in lizards[J]. Theoret Appl Genet, 49: 9-14.

Harris H, Hopkinson DA. 1978. Handbook of Enzyme Electrophoresis in Human Genetics[M]. Amsterdam: North-Holland Publishing Company.

Kingdon J. 1997. The Kingdom Field Guide to African Mammals[M]. Academic Press, London and New York: Natural World.

Nevo E. 1978. Genetic variation in natural populations: Patterns and theory[J]. Theoret Popul Biol, 13: 121-177.

Nevo E, Filippucci MG, Beiles A. 1990. Genetic diversity and its ecological correlates in nature: Comparisons between subterranean, fossorial, and aboveground small mammals[A]. In: Nevo E, Reig OA. Evolution of Subterranean Mammals at the Organism and Molecular Levels[M]. New York: Wiley-Liss, 347-366.

Nevo E, Kim YJ, Shaw CR, Thaeler, CS JR. 1974. Genetic variation selection and speciation in Thammomys talpoides pocket gophers[J]. Evolution, 28(1): 1-23.

Nevo E, Beiles A, Ben-Shlomo R. 1984. The evolutionary significance of diversity: Ecology, demographic and life history correlates[A]. In: Mani GS. Evolutionary Dynamics of Genetic Diversity[M]. Lecture Note in Bioinformatics, 53: 13-213.

Osborn DJ, Helmy I. 1980. The contemporary land mammals of Egypt including Sinai[J]. Fieldiana Zool (Chicago), 5: 1-579.

Pasteur G, Pasteur N, Orsini JP. 1978. On genetic variability in a population of the widespread gecko Hemidactylus brooki[J]. Experimentia, 24: 1557-1558.

Pasteur N, Pasteur G, Bonhomme F, Catalan J, Britton-Davidian J. 1986. Practical Isozyme Genetics[M]. Ellis Harwood Ltd, Chichester, UK.

Pocock RI. 1922. The external characters of Scarturus and other jerboas compared with those of Zapus and Pedetes[J]. Proc Zool Soc London, 1922: 659-682.

Rice WR. 1989. Analyzing tables of statistical tests[J]. Evolution, 43: 223-225.

Selander RK, Johnson WE. 1973. Genetic variation among vertebrate species[J]. Annual Rev Ecol and Syst, 4: 75-91.

Shahin AAB. 2003. Genetic differentiation and relationship of the dipodids Allactaga and Jaculus (Mammalia, Rodentia) in Egypt based on protein variation[J]. Acta Theriol, 48 (3): 309-324.

Shahin AAB, Ata AM. 2001. A comparative study on the Karyotype and meiosis of the jerboas Allactaga and Jaculus (Rodentia: Dipodidae) in Egypt[J]. Zoology in the Middle East, 22: 5-16.

Sneath PHA, Sokal RR. 1973. Numerical Taxonomy: The Principles and Practice of Numerical Classification[M]. Freeman WH, San Francisco, CA, USA.

Vinogradov B. 1930. On the classification of the Dipodidae (cranial and dental characters) [J]. Bull Acad Sci USSR, 1930: 331-350.

Wassif K. 1960. Studies on the osteology of Egyptian jerboas[J]. Bull Zool Soc Egypt, 15: 71-92.

Wolff JO. 2008. Social biology of rodents[J]. Integr Zool, 2(4): 193-204. 